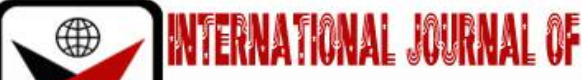

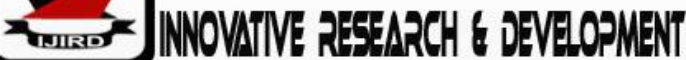

ISSN 2278 - 0211 (Online)

\section{Causes of Examination Anxiety on the Academic Performance of Secondary School Students in Okigwe Zone 1 Imo State, Nigeria}

\begin{tabular}{c} 
Stanley U. Nnorom. \\
Lecturer, Department of Educational Management and Policy, \\
Nnamdi Azikiwe University, Awka, Anambra State, Nigeria \\
Anyanwu Jude A \\
Lecturer, Department of Educational Management and Policy, \\
Nnamdi Azikiwe University, Awka, Anambra State, Nigeria \\
Stephen Ezenwagu \\
Lecturer, Department of Educational management and Policy, \\
Nnamdi Azikiwe university, Awka, Anambra state Nigeria \\
\hline
\end{tabular}

\begin{abstract}
:
The study determined the effects of examination anxiety on the academic performance of secondary school students in Okigwe zone 1 Imo State, Nigeria. The study adopted descriptive survey design. The population of the study comprised 1,035 respondents comprising 60 principals and 975 teachers of public secondary schools in Okigwe zone 1 Imo State, Nigeria. Simple random sampling, 207 principals and teachers were used for the study. Data collection was carried out using Effects of Examination Anxiety Questionnaire (EEAQ) for students. The instrument was subjected to face and content validity by three experts. The test of reliability on the instrument yielded coefficient values $0.75,0.77$ and 0.87 for Sections $A, B$ and $C$ respectively with an overall reliability co-efficient value of 0.80. Data were analyzed using mean. The mean value was used to answer the research questions. Findings revealed that students' individual factors, school factors and parental factors cause examination anxiety among secondary school students in Okigwe zone 1of Imo State. Based on these findings, it was recommended among others that secondary school students should be trained to adopt good study habits, examination halls, provision of teaching materials, teaching aids in secondary schools, engage themselves in academic and physical activities that will adequately prepare them for examinations. It was also recommended that government, counsellors as well as other educators should create enabling learning environment for students free of tension and unnecessary stress so as to minimize anxiety and amongst others.
\end{abstract}

Keywords: Examination Anxiety

\section{Introduction}

Education is an important tool used in the transformation of individuals and the society at large. It is also a process whereby a person develops attitudes and abilities that are considered to have value and relevance in society. It is the best legacy a nation can give to her citizens especially the youth. A good level of education confers on a student a corresponding high level of Meta cognitive skills which in turn helps the student to have a good knowledge of himself as a cognitive processor, and knowledge of task and strategy variables necessary for effective learning (Hoe, Cheong and Yee, 2013).Education plays a critical role in human capacity building and skills acquisition (Olayanju 2014). Hence, Federal Republic of Nigeria (FRN, 2013) in its national policy on education clearly stated that education in Nigeria is an instrument 'Par excellence' for effecting national development. The educational system in Nigeria has been delineated into different levels, namely pre-primary, primary, secondary and tertiary levels of education (FRN, 2013). The secondary level of education is the bridge between the primary and tertiary levels of education. Secondary school education is the form of education students receive after primary school and before the tertian' stage. The importance of secondary education lies in its position both as the bridge between primary and tertiary education and as the agent for preparing individuals for useful living in the society. As indicated by FRN (2013), the broad goals of secondary education in Nigeria are preparing people for useful living in the society and for higher education. The FRN (2013) stated that the goals of secondary education include the supply of trained manpower in the applied science, technology and commerce at sub-professional levels; inspire its students with the desire for self-improvement and achievement of excellence; raise a generation of people who can think for themselves, respect the views and feelings of others; and respect the dignity of labour. In order to achieve these objectives, students' need to be periodically assessed and evaluated through test and examinations in other to ascertain their level of knowledge and competence in the various subjects taught. Though Oruche (2011) noted that 
examination is not the only instrument for assessing and evaluating knowledge, it has emerged as the major yardstick and most practical form of assessment in schools. This has made examination a period of constant activity in secondary schools in Nigeria in general and Okigwe zone1 in particular.

Every year students in secondary schools in Okigwe zone take part in examination at least three times in a school session. The examination periods are seen as the hallmark of every term, it is the stage at which students become more focused on their academic work. However, during this period, some students tend to fall sick and some feel depressed. Coupled with the fact that students perceive examinations as a critical period in the school calendar and are considerably pressurized to the extent that they experience high levels of stress, nervousness and apprehension while taking such examinations (Olaitan \& Moroluyo, 2014). This situation has resulted in some students ultimately missing exams. This situation seem to be prevalent in secondary schools in Nigeria and in Okigwe zone where students tend to visit the health centres more during examination periods. This results because of anxiety among students (Obikeze and Umezulike, 2013). Examination anxiety which is also called test anxiety in research literature is an uneasiness or apprehension experienced before, during and after examination because of concern, worry or fear of uncertainty. It was defined by Zeidner (2008) as a set of phenomenological, physiological and behavioural responses that accompany concern about possible negative consequences or failure on an examination or similar evaluative situation. It is feeling that someone might have in a situation where performance really counts or where the pressure to do well is intense. Test anxiety is not entirely bad. In fact a low level of test anxiety is normal and necessary among the students in order to maintain focus and to galvanize them into action preparing, plotting and perfecting strategies that will guarantee optimum success in the examinations. It is needed to motivate and help the students to stay mentally and physically alert (Birjandi and Alemi, 2010).

However, when the anxiety or level of arousal exceeds that optimal level, the result is decline in performance. It is when anxiety is in its severe form that some students experience genuine problem in academics. Their minds go blank, they experience the shakes, their hands go numb and they suffer from number of sudden disabilities associated with anxiety during examination. Academic performance is the outcome of education. It refers to the extent to which a known to be influenced by anxiety. Some candidates seeking for jobs find it difficult to remember even their own names during interviews for highly paid jobs in such a situation where good performance counts and pressure to do well is palpable (Putwain, Woods and Symes, 2010). It is performance anxiety that makes a professor seat profusely and sounds incoherent almost at the point of collapsing while presenting inaugural lecture with intimidating audience in attendance.

According to Sindln (2005) examination anxiety is a psychological condition in which people experience extreme stress, phobia, discomfort and irrational fear during or before examination.Examination anxiety can serve both adaptive and maladaptive functions; primarily based on the amount of examination anxiety the student was experiencing (Ormrod, 2011). Cassady (2010) posited that the difference between generalized anxiety disorders and examination anxiety is characterized by trait anxiety that results to students experiencing higher levels of stresses across a wide range of situations. In contrast, students that are prone to examination anxiety have a state of anxiety that results to higher levels of nervousness that are specific to examinations. The symptoms of examination anxiety range from moderate to severe anxiety. Various factors in literature have been blamed as instigators of examination anxiety among students. They include individual factors, school factors and parental factors (Patil \& Aithala, 2017).The individual factors that could cause examination anxiety among students in secondary schools are those factors that are personal to the student himself. It has to do with student style of studying, negative and irrational thinking about exams, outcome of inadequate rest, insufficient physical activity and class attendance (Nelson \& Harwood, 2011). According to Oruche (2011), students' attitude to learning and attention in class results in exam anxiety. However, the extent to which these individual factors result in examination anxiety among secondary school students has not been empirically proven. Oruche (2011) also averred that school factors could also result in examination malpractice. School factors seem to be those factors that are in the school system that could cause examination anxiety among students. Such factors include the teachers' method of teaching, examination time table and school infrastructure as well as school location. According to Nelson and Harwood (2011) school infrastructure and procedures could cause examination anxiety among students. Nelson and Harwood noted that inadequate lighting in the classrooms, lack of adequate reading areas, teachers' ability to motivate students and the school curriculum are seem to be some school factors that could influence examination anxiety among students.

\subsection{Statement of the Problem}

Today in Nigeria, as in other parts the world, performance at examination is the yardstick for measuring, judging and selecting manpower, and for assessing students for promotion and the award of certificates. It is little wonder then that many secondary school students in Okigwe zone 1, Imo state have anxiety particularly during examination and this has adversely affected their performance, this is because of the much emphasis laid on examination in schools and by WAEC, NECO and NABTAB that students become convince that sustenance of life into the University depends on their performance in these examinations. They therefore cultivate fear of failures. Because of this failure, they resort to cheating during examinations, some even become involved in certificate racketeering and this attitude towards examination is a major element of the indiscipline of the wider society. In secondary schools, clinical symptoms of test anxiety are made manifest when students start having abnormal rapid heartbeats, sweating palms or body, shivering and spilling their ink during examination. There have been also cases of students going insane or collapsing in examination halls because of such anxiety, these possess a big problem to both schools and society as a whole. The researcher is worried that examination anxiety seems to have made some secondary school students in Okigwe zone 1 to abscond from school and also imbibe other truant behaviour. This seems to have resulted in increased rate of criminal activities among teenagers of secondary school age in the LGA. It is against this background that the study investigated the causes of examination anxiety on the academic performance of secondary schools students in Okigwe zone 1of Imo State. 


\subsection{Purpose of the Study}

Having taken cognizance of the nature of the problem posed by examination anxiety, the purpose of this study is therefore to:

- Find out the causes of examination anxiety on the performance of secondary school students of Okigwe zone 1, Imo state.

- Identify the school factors causing examination anxiety among students of Okigwe zone 1, Imo state.

\subsection{Research Question}

The current researches explore the following research questions:-

- What are the causes of examination anxiety on the performance of secondary school students of Okigwe zone 1, Imo state?

- How school factors cause examination anxiety among secondary school students in Okigwe Zone 1 of Imo State?

\subsection{Significance of the Study}

The findings of the study will be beneficial to the students, guidance counselors, the Ministry of Education, parents and future researchers. Students in secondary schools will benefit from the findings of the study. Through the findings made in the study, the causes of examination anxiety among secondary school students in the LGA will be revealed. Through the recommendations made in the study, students will be educated on ways of managing examination anxiety. This can be done through seminar organized for students based on the findings of the study. Findings of the study will also be beneficial to guidance counselors in secondary school. This is because the counsellors will be exposed to the causes of examination anxiety among students in the L.G.A. The publication of the study in journals and periodicals will know the true causes of examination anxiety among secondary school students. This will enable them adopt effective strategies for curbing examination anxiety among secondary school students. The ministry of education will benefit from the findings of the study. They will know the causes of examination anxiety among secondary school students in the LGA. This would be possible through the presentation of the findings of the study in seminars and conferences organized on causes of examination malpractices, the Ministry of Education could map out strategies or framework for reducing examination anxiety based on the findings of the study. The findings of the study will be of benefit to parents. Through the findings of the study parents will know the causes of examination anxiety in their children. This will improve parents' interest in motivating their children to learn and desist from mounting pressure on them for higher scores in their examination. This can be done through educating parents on their roles in reducing examination anxiety in their children during Parent Teachers Association (PTA) meetings.Finally; this study will be of immense importance to future researchers as this will serve as reference materials to them. This can be done by making the work available on the internet and in the school libraries.

\section{Method}

The research survey design was adopted for the study. The population of the study comprised all the 1,035 respondents made up of all the sixty (60) principals and nine hundred and seventy-five (975) teachers in thirty public secondary schools in Okigwe Zone 1 Imo state, Nigeria. A sample of 207 respondents was selected and the represented $20 \%$ respondents' population. The sample consisted of 6 principals and 195 teachers. Proportionate stratified random sampling technique was used to select the sample. The instrument for data collection was a questionnaire developed by the researcher and titled, 'Effects of Examination Anxiety Questionnaire (EEAQ)' It contained a total of 16 items arranged in three sections according to the three research questions guiding the study. Sections A and B contained 9 and 8 items, respectively. All the items in section A and B are structured on a 4-point rating scale of Strongly Agree (SA), Agree (A), Disagree (D) and Strongly Disagree (SD), weighted 4, 3, 2 and 1 respectively. Draft copies of the instruments were given to three specialists, one specialist from Measurement and Evaluation Department and two specialists from the Department of Educational Management and Policy, Faculty of Education, Nnamdi Azikwe University Awka, Anambra State who carefully reviewed the questionnaire items to ensure its face validity. To establish the instrument's reliability, a pilot test was conducted. The instruments were distributed to 20 principals/teachers in secondary schools in Awka Metropolis that were outside the study area on two occasions within the space of two weeks for the reliability. The data collected were analyzed with Cronbach Alpha and coefficient values of $0.75,0.77$ and 0.87 for Section A, B and C respectively with an overall reliability co-efficient value of 0.80 . These coefficient values indicated that the instrument was reliable for the study. Two hundred and seven (207) copies of the instrument were personally administered by the researchers to the respective principals, and teachers. The respondents completed the instrument on the spot and this ensured a $100 \%$ return rate. In analyzing the data for the study, mean score statistics were used to answer the research questions. Thus, mean scores that are equal to or above 2.5 are considered 'agreed' while those whose mean score was below 2.5 are considered 'disagreed'. For the research questions, the decision rule was based on the lower and upper limits of the mean;

\subsection{Presentation of Findings}

\subsubsection{Research Question 1}

What are the causes of examination anxiety on the performance of secondary school students of Okigwe zone 1 , Imo state? 


\begin{tabular}{|c|c|c|c|c|c|c|c|}
\hline S/no. & $\begin{array}{l}\text { The following students individual } \\
\text { factors cause examination anxiety: }\end{array}$ & $\begin{array}{c}\text { SA } \\
4\end{array}$ & $\begin{array}{l}\mathbf{A} \\
\mathbf{3}\end{array}$ & $\begin{array}{l}\mathbf{D} \\
2\end{array}$ & $\begin{array}{c}\text { SD } \\
1\end{array}$ & $\overline{\mathbf{x}}$ & Decision \\
\hline 1 & $\begin{array}{l}\text { Student style of studying causes } \\
\text { examination anxiety }\end{array}$ & 31 & 63 & 4 & 0 & 3.28 & Agree \\
\hline 2 & $\begin{array}{l}\text { Students' irrational thinking about } \\
\text { exams causes examination anxiety }\end{array}$ & 38 & 60 & 0 & 0 & 3.39 & Agree \\
\hline 3 & $\begin{array}{l}\text { Inadequate rest causes examination } \\
\text { anxiety }\end{array}$ & 25 & 67 & 6 & 0 & 3.19 & Agree \\
\hline 4 & $\begin{array}{l}\text { Insufficient physical activity causes } \\
\text { examination anxiety }\end{array}$ & 34 & 57 & 7 & 0 & 3.28 & Agree \\
\hline 5 & $\begin{array}{c}\text { Students 'poor class attendance causes } \\
\text { examination anxiety }\end{array}$ & 38 & 60 & 0 & 0 & 3.39 & Agree \\
\hline 6 & $\begin{array}{l}\text { Students' inefficient subject content } \\
\text { coverage causes examination anxiety }\end{array}$ & 28 & 70 & 0 & 0 & 3.29 & Agree \\
\hline 7 & $\begin{array}{c}\text { Students' poor self-efficacy causes } \\
\text { examination anxiety }\end{array}$ & 30 & 68 & 0 & 0 & 3.31 & Agree \\
\hline 8 & $\begin{array}{c}\text { Students' lack of academic resilience } \\
\text { can cause examination anxiety }\end{array}$ & 32 & 66 & 0 & 0 & 3.33 & Agree \\
\hline 9 & $\begin{array}{l}\text { Students' not being satisfied with the } \\
\text { achieved academic result in the } \\
\text { previous examination can cause } \\
\text { examination anxiety }\end{array}$ & 28 & 55 & 10 & 5 & 3.08 & Agree \\
\hline & Cluster Mean & & & & & 3.17 & Agree \\
\hline
\end{tabular}

Table 1: Respondents Mean Ratings on Students Individual Factors That Cause Examination Anxiety among Secondary School Students ( $N=98)$

Data in Table 1 reveal that the respondents agree that all items on students individual factors cause examination anxiety among secondary school students in Okigwe Zone 1 of Imo State as reflected in items 1 to 9 with mean ratings ranging from 3.08 to 3.39 . The cluster mean of 3.17 indicate that students individual factors cause examination anxiety among secondary school students in Okigwe Zone 1 of Imo State.

\subsubsection{Research Question 2}

How school factors cause examination anxiety among secondary school students in Okigwe Zone 1 of Imo State?

\begin{tabular}{|c|c|c|c|c|c|c|c|}
\hline S/no. & $\begin{array}{c}\text { The following school factors could } \\
\text { cause examination anxiety among } \\
\text { secondary school students: }\end{array}$ & $\begin{array}{c}\text { SA } \\
\mathbf{4}\end{array}$ & $\begin{array}{c}\mathbf{A} \\
\mathbf{3}\end{array}$ & $\begin{array}{c}\mathbf{D} \\
\mathbf{2}\end{array}$ & $\begin{array}{c}\text { SD } \\
\mathbf{0}\end{array}$ & $\overline{\mathbf{x}}$ & Decision \\
\hline 10. & $\begin{array}{c}\text { Teacher harshness and harassment } \\
\text { causes examination anxiety. }\end{array}$ & 34 & 60 & 4 & 0 & 3.31 & Agree \\
\hline 11. & $\begin{array}{c}\text { Lack of information on examination } \\
\text { dater causes examination anxiety. }\end{array}$ & 39 & 58 & 1 & 0 & 3.39 & Agree \\
\hline 12. & $\begin{array}{c}\text { Lack of information on the venue of } \\
\text { examination causes examination } \\
\text { anxiety. }\end{array}$ & 42 & 38 & 18 & 0 & 3.24 & Agree \\
\hline 13. & $\begin{array}{c}\text { Inadequate coverage of the subject } \\
\text { content to be covered causes } \\
\text { examination anxiety. }\end{array}$ & 54 & 34 & 10 & 0 & 3.45 & Agree \\
\hline 14. & $\begin{array}{c}\text { Strict school rules and regulations cause } \\
\text { examination anxiety }\end{array}$ & 65 & 33 & 0 & 0 & 3.66 & Agree \\
\hline 15. & $\begin{array}{c}\text { Failure to follow examination } \\
\text { instructions cause examination anxiety }\end{array}$ & 56 & 36 & 6 & 0 & 3.51 & Agree \\
\hline 16. & $\begin{array}{c}\text { Sitting arrangement in the examination } \\
\text { hall causes examination anxiety. }\end{array}$ & 7 & 86 & 5 & 0 & 3.02 & Agree \\
\hline & Cluster Mean & & & & & 3.37 & Agree \\
\hline
\end{tabular}

Table 2: Respondents Mean Rating on School Factors that Cause Examination Anxiety among Secondary School Students

Data in Table 2 reveal that the respondents agree that all items on school factors cause examination anxiety among secondary school students in Okigwe Zone 1 of Imo State as reflected in items 10 to 16 with mean ratings ranging from 3.02 to 3.66. The cluster mean of 3.37 indicate that school factors cause examination anxiety among secondary school students in Okigwe Zone 1 of Imo State. 


\subsection{Summary of Findings}

The findings of the study are summarized as follows:

- Students' individual factors cause examination anxiety among secondary school students in Okigwe Zone 1 of Imo State.

- School factors cause examination anxiety among secondary school students Okigwe Zone 1 of Imo State.

\section{Discussion of the Findings}

\subsection{Students Individual Factors as Cause of Examination Anxiety}

Findings on the first research question revealed that students' individual factors cause examination anxiety among secondary school students in Okigwe Zone 1 Imo State. Findings of the study further showed that student style of studying, students' irrational thinking about exams, inadequate rest, insufficient physical activity, students' poor class attendance, students' poor self-efficacy and students' lack of academic resilience were some of the students' individual factors that cause examination anxiety among secondary school students in Okigwe Zone 1 Imo State. These findings are in agreement with Mukolwe (2015) who noted that the factors like student's abilities, study habit and academic resilience were some factors that cause examination anxiety among secondary school students. This shows that the students themselves could influence their exposure to examination anxiety based on their abilities and study habits. In the same vein, Me Donald (2001) noted that the most common reasons of stress like poor study habits, lack of exam preparation and organization, the failure to adjust time and studying a night before an exam. Getting worried about competition and anticipated results, past performances in exams, academic probation are also some other reasons of test anxiety in students.

\subsection{School Factors as Cause of Examination Anxiety}

Findings on the second research question revealed that school factors cause examination anxiety among secondary school students in Okigwe Zone 1 of Imo State. Findings of the study further showed that attitude of subject teacher, lack of information on examination date, inadequate coverage of the subject content to be covered; unconducive examination venue and sitting arrangements in the examination hall were some of the school factors that cause examination anxiety among secondary school students in Okigwe Zone 1 Imo State. This finding is in agreement with Alam and Hardier (2018) who found that factors related to the schools like the school location, infrastructural facilities and course load were factors that cause examination anxiety among secondary school students. In agreement, Pathil and Aithala (2017) found that students respond more positively to better organized courses, led by enthusiastic instructors, who awake students' interest in the subject and succeed in influencing the students' learning process. Hyseni-Duraku (2014) reported that lack of adaptability of the school infrastructure, the academic term functioning methods, and the limited capacity of academic institutions to support the academic efforts of their students could influence examination anxiety among students.

\subsection{Implication of the Study}

The findings of the study have implications for secondary schools administrators, students and parents' schools in Okigwe Zone 1 of Imo State on the need to inculcate practices that will ensure secondary school students are confident and comfortable in the learning. The implication of the study shows that if students continue to have poor study habit, lack of rest and low academic resilience among others, the examination anxiety level of secondary school students will continue to be high. Furthermore, the implication of school and individual factors as causes of examination anxiety among secondary school students would lead to reduced academic performance among secondary school students in Okigwe Zone 1 of Imo State. It is therefore imperative that efforts should be made by all stakeholders to limit the negative influence of these variables on secondary school students in the area.

\section{Conclusion}

Based on the findings of the study, the researcher concludes that students individual factors, school factors and parental factors causes examination anxiety among secondary school students in Okigwe Zone 1 of Imo State. It therefore becomes pertinent that measures are put in place to ensure that the factors identified in the study could be controlled to positively influence secondary school students learning.

\section{Recommendations}

Based on the findings of this study, the researcher proffers the following recommendations:

- Secondary school students should be trained to adopt good study habits, rest well and engage themselves in academic and physical activities that will adequately prepare them for examinations. This can be done through classroom meetings, school assemblies and the use of guidance counsellors.

- Administrators of secondary school should ensure that students are given sufficient time to prepare for examination. This can be done by ensuring that examination time tables are made known to students weeks or months before the exam date.

- Government should ensure that physical facilities are provided in the school system. Such physical facilities include well equipped libraries, conducive classrooms, examination halls, sports facilities, provision of teaching materials and teaching aids in secondary schools, etc. Principals should consistently organize seminars for 
teachers to educate them on the effect of their attitude to students, teaching style and methods on examination anxiety among students.

- $\quad$ Parents should also be encouraged to be actively involved in their children education; however, they should be advised not to be too over bearing in terms of their expectations from their children.

\section{References}

i. Akanbi, S. T. (2010). Test Anxiety as a correlate of academic achievement among senior secondary school in Ogbomoso Area of Oyo State. African Journal of Educational Research, 14(1 \&2), 89-97.

ii. Akomolafe, C. O. (2012). A comparative study of principals' administrative effectiveness in public and private secondary schools in Ekiti State, Nigeria. Journal of Education and Practice, 3 (13), 39-45.

iii. Barlow, D. H. (2002). Anxiety and its disorders: The nature and treatment of anxiety and panic. New York, NY: Guilford Press.

iv. Benveniste, L., Carnoy, M., \& Rothstein, R. (2003). All else equal: Are public and private schools different? New York: Routledge Falmer.

v. Campbell, J. R. (1994). Differential socialization in mathematics achievement: Cross-national and cross-cultural perspectives. International Journal of Education Research, 21, 685-696.

vi. Cassady, J. C. (2001). Cognitive Test Anxiety and Academic Performance. Contemporary Educational Psychology, 27(2), 270-295.

vii. Chen, H. (2012). Impact of parent's socioeconomic status on perceived parental pressure and test anxiety among Chinese high school students. International Journal of Psychological Studies, 4 (2), 235-245.

viii. Cohen, M., Ben-Zur, H., \& Rosenfeld, M. J. (2008). Sense of coherence, coping strategies, and test anxiety as predictors of test performance among college students. International Journal of Stress Management, 15, $289-303$.

ix. Connor, K. \& Davidson, J. R. T (2003). Development of a new resilience scale: The Connor-Davidson Resilience Scale (CDRISC). In V. Bitsikal, C. F. Sharpley \& K. Peters (2004) How is resilience associated with anxiety and depression? Analysis of factor score interactions within a homogeneous sample. German Journal of Psychiatry. Retrieved from http://www.gjpsy.uni-goettingen.de in January 2012.

X. Dubi, N. E. (2014). Evaluation of instructional leadership practices of principals in Nigerian secondary schools (Doctorate dissertation, Department of Educational Foundations and Curriculum, Ahmadu Bello University, Zaria).

xi. Duze, C. (2012). Comparative analysis of principals' management strategies in public and private secondary schools in Anambra State of Nigeria. International Journal of Arts and Humanities, 1 (1), 239-256.

xii. Erlauer, L. (2003). The brain-compatible classroom: using what we know about learning to improve teaching. Association for Supervision and Curriculum Development (ASCD).

xiii. Fairbrother, K. \& Warn, J. (2003), Workplace dimensions, stress and job satisfaction. Journal of Managerial Psychology, 18(1), 8-21.

xiv. Federal Government of Nigeria. (2013). National policy on education (6th ed.). Abuja: NERDC Press.

xv. Hess, B., Sherman, M. F., \& Goodman, M. (2000). Eveningness predicts academic procrastination: The mediating role of neuroticism. Journal of Social Behavior and Personality, 75(5), 61-74.

xvi. Hoe Cheong and Yee (2013) Chinese Overseas Remittances to China: The Perspective from Southeast Asia

xvii. Hyseni-Duraku, Z. (2014). Interplay between academic and personal factors in the academic performance of Bachelor students (Unpublished Doctoral Dissertation, University of Tirana. Albania).

xviii. Hyseni-Duraku, Z. (2016). Factors influencing test anxiety among university students. The European Journal of Social and Behavioural Sciences, 1-8

xix. Inam, S.N., Saqib A. \& Alam, E. (2003). Prevalence of anxiety and depression among medical students of private university. J Pak Med Assoc., 53(2), 44-7.

xx. Lee, J \& Shute, J.V., (2010). Personal and social-contextual factors in academic performance: An integrative perspective on student learning. Educational Psychologist, 45(3), 185-202.

xxi. Malik, S. (2015). Assessing level and causes of exam stress among university students in Pakistan. Mediterranean Journal of Social Sciences, 6 (4), 11-18.

xxii. Matthews, G., Zeidner, M., \& Roberts, R. (2006). Models of personality and affect for education: A review and synthesis. In P.A. Alexander \& P.H. Winne, (Eds.) Handbook of educational psychology (pp. 163-186). Mahwah, New Jersey: Lawrence Erlbaum Associates.

xxiii. McDonald, A. S. (2001). The prevalence and effects of test anxiety in school children. Educational Psychology, 27(1), 89-101.

xxiv. Mohammed, S., Halilu, M. \& Muhammadu (2017). European Journal of Education Studies, 3 (5), $796-806$.

xxv. Mukolwe, A. (2015). Selected correlates of examination anxiety and academic performance of students in public secondary schools in khwisero sub-county, kakamega county, Kenya. (Unpublished Master's Thesis, Educational Psychology in the School of Education of Kenyatta University).

xxvi. Nelson, J. M., \& Harwood, H. (2010). Learning disabilities and anxiety: A meta-analysis. Journal of Learning Disabilities, $44(3), 2-17$.

xxvii. Olaitan, A. W. \& Moroluyo, A. T. (2014). Contributions of Test Anxiety, Study Habits and Locus of Control to Academic Performance. British Journal of Psychology Research, 2(1), 14-24.

xxviii. Olayanju, O.J. (2014), 'Historical analysis of the implementation of teacher education policy in Nigeria: 18962013', International Journal of Special and General Education 3:131-154.

xxix. Oludipe, B. (2009). Influence of test anxiety on performance levels on numerical tasks of secondary school physics 
students. Academic Leadership, 7 (4), 23-28.

xxx. Onyeizugbo, E. U. (2010). Self-efficacy and test anxiety as correlates of academic performance. Educational Research, 1(10), 477-480.

xxxi. Ormond, K. (2011). The Prevalence and Effects of Test Anxiety in School Children. Educational Psychology, 27(1), 89-101

xxxii. Oruche, E. (2011). Test anxiety and academic performance in undergraduate and graduate students. Journal of Educational Psychology, (97). 268-274.

xxxiii. Patil, S.G. \& Aithala, M.R. (2017). Exam anxiety: Its prevalence and causative factors among Indian medical students. National Journal of Physiology, Pharmacy and Pharmacology, 7(12), 1323-1328.

xxxiv. Peleg, 0. (2009). Test anxiety, academic achievement, and self-esteem among Arab adolescents with and without learning disabilities. Learning Disability Quarterly, 32, 11-20.

xxxv. Prince-Embury, S. (2005). Resiliency Scales for Children and Adolescents -A profile of Personal Strengths (RSCA). In L. Connors, D. Putwain, K. Woods \& L. Nicholson (2009). Causes and consequences of test anxiety in Key Stage 2 pupils: The mediational role of emotional resilience. Examination Anxiety in Primary, Secondary and Sixth Form Students Symposium presented at the British Educational Research Association Conference 2nd - 5th September 2009. University of Manchester.

xxxvi. Putwain, D. W. (2007). Test anxiety in UK schoolchildren: Prevalence and demographic patterns. British Journal of Educational Psychology, 77, 579-593.

xxxvii. Putwain, D. W. (2009). Assessment and examination stress in key stage 4. British Educational Research Journal, 35, 391-411.

xxxviii. Putwain, D. W., Woods, K. A., \&. Symes, W. (2010). Personal and situational predictors of test anxiety of students in post-compulsory education. British Journal of Educational Psychology, 80, 137-160.

xxxix. Ranchman, S. (2004). Anxiety (2nd ed.). New York: Psychology Press Ltd.

xl. Sansgiry, S. S. \& Kavita Sail, B.S. (2006). Effect of student's perceptions of course loads on test anxiety. American Journal of Pharmaceutical Education, 70 (2), 1-6.

xli. Sirois, F. M. \& Pychyl, T. A (2002). Academic procrastination: Cost health and well-being. Presentation at APA convention, August 22, 2002, Chicago, Illinois. Retrieved from http://www.carleton.ca/ typcyl/prg/conferences /apa2002/apaslides 2002/sld001.ht, in December 2011.

xlii. Udalla, N. (2012). Principals' administrative effectiveness in secondary schools in Anambra State (Master's thesis, Department of Educational Management and Policy, Nnamdi Azikiwe University, Awka).

xliii. Weiner, B. A., \& Carton, J. S. (2011). Avoidant coping: A mediator of maladaptive perfectionism and test anxiety. Personality and Individual Differences, 52, 632-636. 